\title{
Mathematics Education in Ethiopia in the Era of COVID-19: Boosting Equitable Access for All Learners via Opportunity to Learning
}

\author{
Solomon Abedom Tesfamicael ${ }^{1 *}$ (1), Yenealem Ayalew ${ }^{2}$ (1)
}

\author{
${ }^{1}$ Department of Teacher education, Norwegian University of Science and Technology (NTNU), NORWAY \\ ${ }^{2}$ Dire Dawa University, ETHIOPIA \\ *Corresponding Author: solomonabedom@gmail.com
}

Citation: Tesfamicael, S. A., \& Ayalew, Y. (2021). Mathematics Education in Ethiopia in the Era of COVID-19: Boosting Equitable Access for All Learners via Opportunity to Learning. Contemporary Mathematics and Science Education, 2(1), ep21005. https://doi.org/10.30935/conmaths/9680

\begin{abstract}
In the one hand, the world is not yet secured from COVID-19. On the other hand, educational planning is a continuous activity. The Federal Democratic Republic of Ethiopia is going to implement new curricula since 2021/22 academic year. So, what lessons or challenges could be derived from this era? This might be an opportunity for educators and researchers to forward inputs to the decision making bodies. In this article, the construct "opportunity to learning" (OTL) is taken as a parameter for addressing one of the goals of education: equitable access in mathematics education. This was done by adopting two frameworks: NCTM \& NCSM (2020) and Walkowiak, Pinter, \& Berry (2017). Finally, we come up with ten discussion points in order to boost the equitable access for all learners. Our work may serve as a position paper to inform curriculum implementers and educational material producers in countries like Ethiopia.
\end{abstract}

Keywords: equitable access, mathematics education, opportunity to learning

Received: 22 Sep. 2020 Accepted: 24 Nov. 2020

\section{INTRODUCTION}

The year 2020 has been a terrible season for people of the world due to the corona virus (COVID-19). The virus has been spreading throughout the world. It has disrupted many sectors and in particular schools; it posed uncertainty on educational programs. It also creates doubt on whether to be robust or not in the coming school year(s). Who knows COVID-19 can cause reforms across nations, maybe remote learning or blended learning at an unprecedented level, especially, at the tertiary level (Mulenga \& Marbán, 2020; Radcliffe, 2020)? This would not be different for Ethiopian case. Fortunately, the country is going to make effective new curricula since 2021/22 academic year.

We assumed that the season might be a turning point for paradigm shift in the education system. To exemplify the instance, we can provide two different happenings that cause educational reform. Six decades ago, the launching of the Sputnik satellite (by the former Soviet Union) triggered educational funding for education at all levels (NCTM 1989, 1991, 1995; Tesfamicael, 2019). Another occasion happened in Germany when PISA (Programme for International Student Assessment) tests of 15-year-old students from all over the world scores in mathematics was lower than the OECD average (OECD, 2000). This created shock, called PISA shock, and triggered school reform in the country (Davoli, 2018). Not only Germany but also many other countries, including Norway, has undergone some educational reforms (Grønmo, 2010).

We have learnt that 'the future is uncertain'. Yet, what kind of opportunity are we arranging for students? Having such states of affairs in mind, what is at a stake is access for learners. Cai et al. (2020) referred to learning opportunity or opportunity to learn $(O T L)$ as the best indicator of student learning. They encourage researchers to engage on how to maximize the quality of learning opportunity which is taken as a systemic parameter for boosting equity in mathematics education. Opportunity to learn is taken as a credible construct to deal on the issue of equitable access, especially, to overcome the inequality due to the existing disruption of schooling after COVID-19 pandemic.

\section{The Problem Statement}

When we browse on mathematics education during this pandemic, we found a report that says: "COVID-19 exposes Mathematics Education inadequacies" (Tanton, 18 April 2020). What does it mean? The challenges related to the teaching and learning of mathematics in this COVID-19 pandemic season is huge. Even before the pandemic challenge, the access for equitable mathematics education was a distant matter to attain in countries like Ethiopia. An educator Dawit Tibebu Tiruneh already expressed his concern that there were pre-COVID-19 inequalities in access to quality education between children in urban 
and rural localities, and children from parents with higher and lower socio-economic status. Besides, he noted that "there are signs suggesting that the Virus could have a lasting impact on increasing inequality (Tiruneh, June 2020).

At the beginning of this academic year, Million Matiwos, a State Minister of Education, gave a statement to the Media on the situation related to the re-opening of schools. He told that lower-grade level students would be given priority based on three shifts. Similarly, Samuel Kifle $(\mathrm{PhD})$, a State Minister of Science and Higher Education, confirmed that undergraduate students would be admitted based on seniority first principle. However, a directive has been expected from the Ministry of Health. But, how would be the treatment of other students?

The Ministry of Education has TV and radio broadcasting services dedicated to reaching students at public schools. Yet, such electronics are locked down there due to the pandemic virus. On the other hand, private schools have been initiating remote learning by delivering assignments \& homeworks via telegram channel. At the end of the academic year, a free promotion [for all to the next grade level] was declared due to COVID-19. Nevertheless, grade 10 and 12 students are expected to take national examinations. The problem is that there is poor technology infrastructure and use of ICT to conduct online examinations.

It is not difficult to imagine the serious impact of the corona virus pandemic on universities in executing their day-to-day activities, and thereby the impact on achieving their core missions (Adamu, 07 May 2020). Some public universities in the country had promised to continue and complete their programmes according to their academic calendar; courses were planned to be delivered through online learning platforms. It was only and partially observed in postgraduate students. Such problems might worsen when it comes to teaching learning of mathematics. In the broad-spectrum, NCTM and NCSM (2020) recommended that mathematics should be among the subjects that should be prioritized in the planning of the school for year 2020/21.

So, the main objective of this article is just to unveil the Ethiopian perspective of mathematics education in this era of COVID-19 in terms of OTL. It may serve as a position paper to inform educational material producers. Further, the challenge created by the virus on teachinglearning is taken as an opportunity to point out the limitations of mathematics education programmes in the country that existed even before the pandemic.

\section{A LOOK AT TWO THEORETICAL FRAMEWORKS}

In this article, we have consulted two frameworks in order to show how equitable access in the teaching and learning of mathematics during COVID-19 season can be achieved. The first is adopted from the joint work of Equity Leadership in Mathematics Education (NCSM) and the National Council of Teachers of Mathematics (NCTM) recent recommendations in connection to effective practices for equitable access to high-quality mathematics teaching and learning (NCSM \& NCTM, June 2020). The other one deals with the concept of opportunity to learn, OTL, (Walkowiak, Pinter, \& Berry, 2017). We think that boosting the OTL in the teaching and learning of mathematics can be best approached by all the decision makers: educators, subject specialists, teachers, policy makers, parents and students together in the sense of overcoming the challenges created by COVID-19 school disruption. Collaboration across/among educators, policy makers, teachers and parents to optimize every student learning is a key for success during this school disruption times. On the other hand, NCSM and NCTM's proposed effective practices that are related to structural consideration, teaching practices, and advocacy. In this article, we dare to adopt this framework in order to contribute to the existing discussion in the country. The following three elements of effective practices for equitable access are used as one of the dimensions of the matrix entries analysis proposed in this article.

Structures: - Productive structures that organize students include: engaging students in heterogeneous grouping for instruction; provide differentiated support for each student to reach grade-level standards; provide just-in-time interventions during the school day that do not replace daily, grade-level instruction and are designed on the basis of the results from effective formative assessments. While productive support for teachers include using looping and team teaching (co-teaching) models for teaching assignments; participate in regular professional learning to grow their skills and collaborate to plan effective and flexible instruction for their students.

Teaching Practices supporting Mathematics teaching and Learning: - These include determining essential learning for all students; determining necessary prior knowledge; what students already know and introducing new learning using formative assessment strategies and using effective teaching practices (NCTM, 2018).

Advocating for Teachers, Students, and Humanizing the Development and Implementation of Education Policies and Practices: - This is about promoting high-quality, equitable mathematics teaching and learning for every student (NCSM, 2020a; NCTM, 2014). Especially, during this COVID19 season advocating for policy and budget, assessment practices and professional learning and collaboration should be discussed.

On the other hand, Walkowiak et al. (2017) re-conceptualized the concept of "Opportunity to learn (OTL)" by assuming that developing conceptual understanding. They developed OTL framework that constitutes:

- Mathematical Knowledge for Teaching (MKT)

- Time Utilization,

- Mathematical Tasks, and

- Mathematical Talk.

As an extension of Shulman (1986) work Rowland (2014) defined Mathematical Knowledge for Teaching (MKT) as follows: Every profession like physicians, lawyers, priests, plumbers, motor mechanics, and so on has its own distinctive knowledge base. It is a fact that most of us could not do what lawyers, plumbers, and the rest, do. In a similar way there is increasing recognition that effective teaching calls for distinctive forms of subject-related knowledge and thinking. Hence MKT is the knowledge mathematics teachers need to teach mathematics effectively. There is a continuous debate on what it means to be an effective way of teaching mathematics. Skemp (1986) provided two different types of mathematical understanding that can dominate 


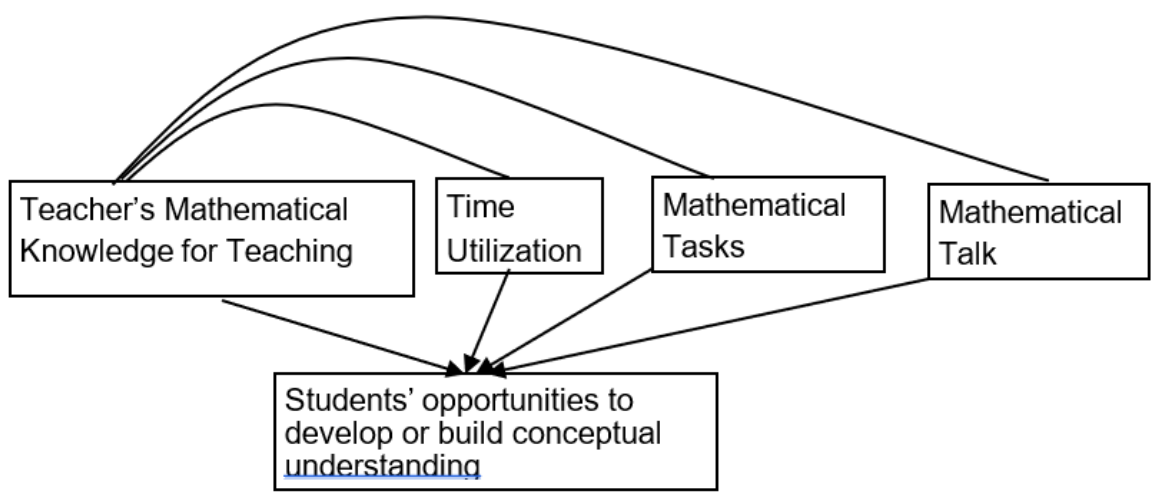

Figure 1. Re-conceptualized “Opportunity to Learn”

Table 1. Reconceptualized OTL Framework: Dimensions and their Respective Features

\begin{tabular}{ll}
\hline Opportunity to Learn Dimension & Dimension's Feature \\
\hline Teacher's MKT & $\begin{array}{l}\text { 1. The lesson content is mathematically accurate } \\
\text { 2. The lesson promotes accurate conceptions among students }\end{array}$ \\
\hline Time & $\begin{array}{l}\text { 1. The majority of time in the lesson is used to reach the mathematical goal. } \\
\text { 2. The time is structured so that the lesson components build on each other with explicit attention to the mathematical goal }\end{array}$ \\
\hline Tasks & $\begin{array}{l}\text { 1. The implementation of tasks is student focused, allowing students to make sense of the mathematics } \\
\text { 2. Tasks involve the use of and translation among two or more representations }\end{array}$ \\
\hline Talk & 1. Students have opportunities to explain their mathematical thinking \\
& 2. Talk is utilized to move students toward a deeper understanding of the mathematical goal
\end{tabular}

the teaching and learning in mathematics: instrumental and relational understanding. The competencies or knowledge required to be effective mathematics teacher or Educator in the $21^{\text {st }}$ century is in general complex, global and local context based, and even difficult to attain (Ball, Thames, \& Phelps, 2008; Jaipal-Jamani \& Figg, 2015; Mishra \& Koehler, 2006; Neubrand et al 2009; Niss, 2002; Rowland, Huckstep, \& Thwaites, 2005; Shulman, 1986; Tesfamicael, 2019). Walkowiak et al. (2017) identified two aspects of Teacher's MKT in relation to OTL: mathematical accuracy and if the lesson promotes accurate conceptions among students (See Table 1).

Time is a key resource in life. Quality time in mathematics teaching and learning can have a huge impact on student learning (Carroll's 1963). In this OTL framework, two aspects are detailed further: Does the majority of the time is used to reach mathematical goals and if it is also structured well to attain the mathematical goals (See Table 1). Mathematical Task is the third component of this framework. Tasks are divided into two: cognitive High and low-demand tasks (Stein, Smith, Henningsen, \& Silver, 2009). All mathematical tasks that are found in a given textbook do not provide the same OTL for learners. For example, is the task student centered or does it encourage the students to use different representations and connect them? This is an interesting aspect that will promote higher learning.

The fourth component of the OTL framework is about Mathematical Talk. It falls under the board construct called mathematical discourse which is one of the effective practices in the teaching and learning of mathematics (Franke, Kazemi, \& Battey, 2007; NCTM, 2014; Smith \& Stein, 2011). Teachers can capitalize on students' talk in order to orchestrate meaningful discourse. Further dimension features under OTL framework are given in Table 1.

\section{OPTIMIZING EQUITABLE ACCESS FOR ALL LEARNERS IN MATHEMATICS TEACHING AND LEARNING DURING COVID-19 SCHOOL DISRUPTION}

In NCTM (2014), one reads "an excellent mathematics program requires that all students have access to a high quality mathematics curriculum, effective teaching and learning, high expectations, and the support and resources needed to maximize their learning potential." This is a challenge for many advanced education systems in the world, let alone for the developing world, even before COVID-19 school disruption. In this article, how to optimize equitable access for all learners in mathematics teaching and learning is induced using two frameworks discussed above as two coordinate axes. The entries of the matrix generated from these frameworks would help us as a framework on how equitable access for all learners can be attained. From a 4 × 3 matrix we get 12 entries, and these serve as a tool to communicate the decision makers at all levels (See Table 2). In these regards, potential resources could be textbooks (both paper and digital), teachers, parents, friends/classmates, senior students, Television/Radio programs, social media and channels and Internet services.

\section{OTL from the Structure}

OTL refers to opportunity to learn as defined by Cai et al. (2020). By "structure", we address the issues of organizing students and supporting teachers. In the following few paragraphs, we present opportunity to learning from the structure point of view.

\section{Structure and MKT}

During this demanding time the lesson content may not be mathematically accurate and student misconception of mathematical misconceptions may be increased due to limited instruction. Engaging students in heterogeneous grouping for instruction and providing differentiated support for each student to reach grade-level standards 
Table 2. Matrix Helping to Optimize Equitable Access for all Learners

\begin{tabular}{llll}
\hline & Structures & Teaching Practices & Advocacy \\
\hline Mathematical Knowledge for Teaching (MKT) & (MKT, Structures) & (MKT, Teaching Practice) & (MKT, Advocacy) \\
\hline Time Utilization & (Time, Structures) & (Time, Teaching Practice) & (Time, Advocacy) \\
\hline Mathematical Task & (Task, Structures) & (Task, Teaching Practice) & (Task, Advocacy) \\
\hline Mathematical Talk & (Talk, Structures) & (Talk, Teaching Practice) & (Talk, Advocacy) \\
\hline
\end{tabular}

can compensate for inconsistencies from lessons. If teachers use effective formative assessments strategies to provide just-in-time interventions during school time, then they may assess those groupings how they can benefit each learner. In Ethiopian case, it is a tradition that such groups (formal like 0ne to 5 group pairing or informal group pairing according to each student's personal networking). After all, Ethiopian context tells us that there is high socialization in the society in comparison to the west's privacy oriented community. That social trend can be used to fill the missing.

Productive structure includes using looping and team teaching (coteaching) models for teaching assignments. This is already implemented in the grades 1-4, but 5-8 and 9-12 are specialized subject teachers who may not necessarily teach consecutive grades. One other aspect mathematics teachers can use during this COVID-19 school disruption season is that they increase participation in some kind of professional learning programme, formal or informal at school level, to grow their skills and collaborate to plan effective and flexible instruction for their students. In theory, one learns well in social context or community of practice in participation (Lave \& Wenger, 1991; Lerman, 1996; Wenger, 1998). Do we have such structures at the ground already? If yes, deliberate decision has to be made to continue, if not creating new ones has to be the immediate action. Teachers need both emotional and academic professional support at this very moment regarding their MKT as the time needs flexibility at least.

\section{Structure and time utilization}

Time is the parameter at stake during corona disruption. Means students and teachers contact hour is limited. Hence the relationships like student-student, or teacher-student is not at its optimal level. How can students and teachers utilize their time on the goals of mathematics at each grade level in an optimal way when the time of contact is limited? In countries like Norway, when the in-person instruction was interrupted due to COVID-19, the remote learning system was utilized in an efficient manner. As one of us is a parent, assisting the child at home in the virtual learning system went well. As the virtual system is ready to be used in the system, the digital literacy level of the pupil and the teachers is at sufficient level to keep schooling. Even later when a hybrid or blended learning system (in -person and remote instruction) was utilized, the students managed to cover the goals of instruction. But in countries like Ethiopia, virtual learning is a distant matter. Teachers, parents and children, digital literacy is at stake here. The digital system is not at a level where one can undergo formal education. Hence time utilization on essential learning goals is vital. Few students in the capital city from well to do families and private schools may not be as affected by the situation. But the very majority of pupils from public schools and rural areas are affected in this regard and an extra focus should be rendered on it for all learners to get quality mathematics instruction.

\section{Structure and task}

Mathematical tasks that provide learning opportunities for pupils are crucial. Tasks that have multiple entry points, tasks that have high cognitive skills and tasks which are open are supported by recent literature. Such tasks can be discussed in heterogeneous groups among the students if teachers are able to provide tasks to heterogeneous groups of students with different skills and talents. To be aware of the mathematical tasks is one thing that mathematics professionals have to be aware of during this season. Not only to be focused on rote memorization tasks and procedural/algorithmic oriented tasks. Even tasks related to the context of corona can be designed. But this needs professionals to be aware of its presence in the community: like how many infected, how many sick, or admitted, their percentage, and also the prediction.

\section{Structure and talk}

Currently, there is a clear focus on mathematical discourse for better learning. The social turn in mathematics (Lerman, 2000) has a significant impact in the teaching and learning of mathematics. In social cultural theory, learning happens in social context, via discourse or communication. As listening, talking is part of the discourse. The more learners talk about their mathematical thinking with other students, teachers and parents, the more they gain understanding. The question is, is it possible to provide opportunity in the formal and informal structure of the educational system? We believe one thing this COVID19 season has influenced society is to have social distance. Can social distance reduce the amount of such talk? The answer is "yes", especially, in countries like Ethiopia, where other remote communication means are not so available. As a parent of a child in Norway, we witness the engagement of pupils on digital learning platforms that were integrated in the education system way before the current havoc, intensively to compensate the one lost in physical contact. We recommend nations to invest in remote learning systems and digital platforms to integrate in the education system. But for now, is it possible that parents, other senior students in the vicinity help students? Can there be a "debo", Amharic word, for mobilizing the community for helping each other? We remember, the Dergue regime in the past has done such mobilization to eradicate illiteracy in the country by involving anyone who can help to do that. In this case, can those who are in high school talk to the ones in elementary? Can those in the colleges and universities talk to high school students? It is possible. This can boost OTL for every learner.

\section{OTL from the Teaching Practice}

How does the opportunity to learn relate to teaching? Or, what a teaching practice could give opportunity to learn?

\section{Teaching practice and MKT}

NCTM (2014) provides eight effective teaching practices in the teaching and learning of mathematics regardless of whether instruction is in-person, remote, or hybrid. These are to establish mathematical goals to focus learning, implement tasks that promote reasoning and problem solving, use and connect mathematical representations, facilitate meaningful mathematical discourse, pose purposeful questions, build procedural fluency from conceptual understanding, support productive struggle in learning mathematics, elicit and use evidence of student thinking. The goal here is not 
to deal with all these principles. It needs its own huge space and even its own course, maybe. But it is to indicate the kind of teaching practices that can facilitate in providing OTL for every student.

These practices are founded on studies like the one given in Ball et al. (2008), in which the researchers synthesized mathematical knowledge for teaching into many aspects like Common Content Knowledge (CCK), Specialized Content Knowledge (SCK), Horizon Content Knowledge (HCK), Knowledge of Content and Students (KCS), Knowledge of Content and Teaching (KCT) and Knowledge of Content and Curriculum (KCC). Teachers equipped with HCK, KCS are more likely to determine essential learning for all students. They can anticipate what they need as prior knowledge for future lessons and they can discern what students already know before introducing a new concept. Moreover, teachers with skills like formative assessment strategies and using effective teaching practices (NCTM, 2018) are highly likely to be successful in creating OTL for every learner in COVID-19 era.

In the case of mathematics teachers training in Ethiopia, it is not yet clear how such practices are integrated in the pre-service or in-service programs. So far, the teacher education follows the traditional way of training, in which teachers take many high level mathematics courses in addition to some pedagogical courses (Tesfamicael et al., 2018). Such programmes alone cannot equip teachers to be equipped for such a time like this.

\section{Teaching practice and time}

Discussing about time utility in mathematics education is mostly about spending appropriate time on the mathematical goals. The establishment of clear goals helps focus students' attention during a lesson to be on the intended learning outcomes (NCTM, 2014). On the other hand, Fosnot and Dolk (2001) argued that learning goals are situated in the learning trajectories composed of strategies, big ideas and models in mathematics. In their perspective, learning is messy, it has no one single trajectory. Learning progressions or trajectories describe how students navigate from one concept, procedure, big idea or representation to another, which can show students prior and posterior knowledge as they progress to more sophisticated understandings (NCTM, 2014). This transition takes time. How teachers make decisions to utilize the time is one of the demanding competencies during planning, especially, when the time available is constrained under the social distancing regulation imposed by the governments of nations.

\section{Teaching practice and task}

One of the effective teaching practice principles according to NCTM (2014) is implementing tasks that promote reasoning and problem solving. Not all mathematical tasks provide OTL for learners. In fact, tasks that require mere memorization and procedure do not nurture creativity, critical thinking and problem solving in real life contexts. Tasks that are open and high cognitive demanding ones are recommended for optimal student learning. In addition, tasks that nurture learners ability to use multiple representations and their connections boosts student learning (Boaler, 1998; Stein \& Smith 1998; Stein et al., 1996).

\section{Teaching practice and talk}

Mathematical discourse among students is another principle for effective teaching practice in mathematics education. It includes the purposeful exchange of ideas through classroom discussion (talk, listen, write), as well as through other forms of verbal, visual, and written communication. It is said that discourse creates opportunities for students to learn what mathematics is and how one does it (NCTM, 2014). Creating an effective discourse, so that all students benefit from it, is a bigger challenge for teachers during this season than ever social distancing is implemented at all levels of life during COVID-19. For example, how teachers can orchestrate effective classroom discussion, via the five practices of Smith and Stein (2011) (anticipating, monitoring, selecting, sequencing, and connecting) is not clear, when there is such uncertainty to hold the whole class involving instruction.

Talk alone cannot bring meaningful classroom discussion but it is the first step a teacher can do for effective discourse to happen. Talk provides students opportunities to explain their mathematical thinking and it can move students toward a deeper understanding of the mathematical goal (Walkowiak et al., 2017). Kazemi and Hintz (2014) provided different points about "intentional talk" that can help to create a classroom where all of the students in a class can engage in mathematical discussions. The details are deferred to reference given here.

\section{Advocacy for OTL}

In March 2019, NCTM’s president, Robert Q. Berry, message one finds the text "Much of my advocacy work has been primarily in social and community spaces because I recognize that education is not divorced from politics. As educators we must engage in political advocacy to improve the conditions of education and to provoke structural changes to those policies and practices of schooling that exacerbate inequalities within society." In line with this, as educators, we believe that advocacy for the improvement of mathematics education should be the norm in order to boost quality mathematics education for all learners. Recently, we have written a project for NORHED II call with the same title. NCTM and NCSM jointly have come up with three critical areas for advocacy during this COVID-19 era: policy and budget; assessment practices; and framing support for teacher professional learning and collaboration. Together with the reconceptualized concept of OTL of Walkowiak et al. (2017), in the context of Ethiopian education system is assessed as follows.

\section{Advocacy of MKT}

Students' learning and achievement is affected by many factors. Among all these players, there is one factor that stands out: quality of teachers. Teachers' experience, teacher education background, beliefs and motivations, as well as their content knowledge, pedagogical content knowledge, and general pedagogical knowledge (actual and perceived) with their quality teaching or instruction in the classroom (Blömeke, 2016) matters. In the teaching and learning of mathematics, MKT is one aspect that policy makers should aim to improve for every teacher. There is a paradigm shift in how professional development/learning is happening in the world. That is from sit and get, drive-by, one size fits all, and disconnected from teachers' classroom and students to a Job-embedded, Content focused, collaborative, using models \& modeling, coaching, feedback and reflection, and ongoing professional development programmes (Hunzicker, 2011; Venn et al., 2012; Yoon et al., 2007).

Especially when it comes to developing teachers' skill in remote and hy-brid instruction cases, it requires extra planning, budget and policy. First, the importance of such programmes should be advocated well by 
those who are responsible bodies. Remote pedagogy, remote teaching, and remote learning are much more difficult than the in-person one. As part of EdTech and corona virus (COVID-19) series, McAleavy et al (2020), stated the following as the best practice for remote teaching: "The Chinese authorities reviewed the literature and identified key pedagogical risks in moving to remote learning: teachers can be overwhelmed by the duration challenge of organizing online resources; teachers need training or support when moving to remote pedagogy; some learners lack mature skills in self-regulation and independent study." This could be the case in Ethiopia too. Teachers need extra support. Remote learning and digital learning may be the future, the question is how remote or digital learning can it be done effectively. Investment on teachers' professional development in this respect can make a huge difference in the future. One can ask further, what are the initiatives/plans/strategies by those bodies responsible to improve/assist teachers' competencies during this time? Is that enough?

\section{Advocacy and time utility}

When time resources are scarce or limited as in this season, corona spreading time, teacher's time management on instruction (in-person, remote, or hybrid) is crucial. The above mentioned effective teaching practices have immense impact on how teachers manage their time in their lesson to reach the mathematical goal and on how they can structure so that the lesson components build on each other with explicit attention to the mathematical goal. Spending time without deliberate planning and strategy can not help teachers create OTL for every learner. Some learners may need more time than others on some mathematical concepts and procedures. How to help those who are in need requires efficiency in the eight effective practices.

\section{Advocacy and task}

The importance of Tasks as opportunity for mathematics learning can not be overemphasized. Posing problems and tasks has been advocated by many researchers to improve student learning by nurturing mathematical thinking, creativity, discourse in mathematics (Cai et al., 2019; Kilpatrick, 1987; NCTM, 2000; Silver, 1997). In a country where the textbooks are the only major source of mathematical tasks for students and teachers, it is vital to design quality tasks. Textbooks are dominated with tasks that are not open-ended and require mostly memorization, which is a low-level cognitive demand type task (Tesfamicael \& Lundeby, 2019; Tesfamicael et al., 2017). Hence, we recommend that supplementary materials for teachers can be prepared for them to use it during this season. These materials should have a teacher guide as the tasks themselves can be difficult for the teachers to use them appropriately. There can also be a short professional training via social media and channels like Telegram, Viber, WhatsApp and so on.

\section{Advocacy and talk}

Now, how can one nurture the culture of mathematical talk in the time of social distancing? This is problematic even before COVID-19. The Ministry of Education in Ethiopia had been advocating a "one to five" way of organizing groups in classrooms. From the perspective of social cultural theory, learners can use their language to communicate their thoughts and learn from each other (Lampert \& Blunk, 1998), as knowledge is constructed socially according to this theory (Lerman, 1996, 2000). But the problem is that it is highly politicized as the notion is used in every part of the society. The group formation itself was not dynamic, flexible and creative. Instead, it was a locked one, and it served the ruling party as means to control and govern the society. If such grouping could be somehow flexible and authentic, that group talk could enhance learning. The means of talk can also use technology (social media, TV, Internet, Channels). That is not only in the in-person instruction; it is also possible to implement it in the remote and hybrid learning also. The other bottleneck could be how many teachers and students have the privilege to get such resources. As education is a key for a society, the government and other partners can invest in this direction.

\section{SUMMARY OF RECOMMENDATIONS AND CONCLUSION}

As COVID-19 pandemic continues to challenge societies, and as countries implement measures such as 'social distancing' and full/partial school closure, decide makers on education need support from researchers in the field. If large scale vaccine development and intervention is a distance matter for countries, the challenge posed by this pandemic can be changed/converted to opportunity in many aspects: parental engagement increase, advancing remote learning (online learning), budget increment (priority), training new teachers in the education systems (Reimers \& Schileicher, 2020). Further, we argue that it is an opportunity for subject specialists educators like mathematics educators/researchers participation.

In this article, the construct "opportunity to learning" (OTL) is taken as a parameter for addressing one goal of education: equitable access in mathematics education. We adopted two frameworks: (i) NCTM and NCSM (2020) a framework to address mathematics learning in the era of COVID-19 (structures, teaching practice and advocacy); and (ii) the article by Walkowick et al (2017) on the opportunity to learn (OTL) which took four elements: MKT, Time, Task and Talk. Then, we come up with 10 discussion points in order to boost the equitable access for all learners.

1. Using the Social capital in the country. As a consequence of the social-cultural learning theory, there is a social turn in mathematics education (Lerman, 2014). The existing social capital in the culture can be utilized for proactive teaching and learning in the country. It is possible to apply the the concepts of "debo", "zemecha", "one to five", "edir" and so on to boost opportunity for learning for every learner by involving parents, senior students for junior, and so on. For instance, engaging voluntary students as assistant teachers and involving parents in home schooling can be mentioned.

2. Prioritize teaching and learning of mathematics. As mathematics is a difficult subject for many learners, it is vital to prioritize creating OTL for learners. That means time utility for critical conceptual understanding is vital. Apply time multiplexing: divide the number of students in a classroom (some students come in some of the periods and other in the rest). Use 6 days in a week and half of the students can come 3 days in a week and others can come on the other 3 days.

3. Provide Tasks that promote higher OTL for learners. Curriculum developers, text writers, subject specialists, and researchers should provide supplemental materials organized by tasks that promote critical thinking, reasoning, problem 


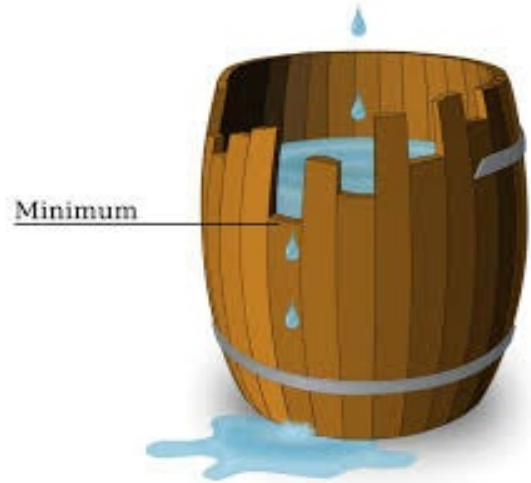

Figure 2. Liebig's Law

solving and modeling are preferable than those meaningless repetitive tasks.

4. Opportunity for mathematical Talk. As part of mathematical discourse, talk is one of the elements of OTL for learners. Evidence of student thinking and learning can be visible when learners begin to talk about their conceptual and procedural understanding. As "social distancing" is enforced, it can be easy to isolate learners. Hence, a deliberate plan is needed for nurturing talk by using existing structures.

5. Boosting practice via MKT. Teachers are key means to students' learning. The quality of mathematics teacher training can improve student learning. MKT is one construct researchers are engaged in equipping teachers to boost the quality of OTL.

6. Focusing on important learning goals at a grade level as a means to boost OTL for all learners. Spending appropriate time on essential learning goals that are suitable in the learning progression. This would allow Teachers, parents and leaders to be pragmatic.

7. Advocating on policy and budget. COVID-19 era school disruption demands education systems to support schools with extra on-line activities, connectivity, Television and radio instruction (Reimers, \& Schileicher, 2020). Going to digital demands an extra budget and policy making. For that, mathematics educators, teachers should advocate for it.

8. Advocating on assessment. Teachers are expected to be equipped well: to plan their instruction based on the data collected, to do assessment for learning and assessment of learning (Chigonga, 2020). So, assessment might be conducted flexibly, for instance, by waiving, eliminating or postponing some national or local summative assessments and focusing or embedding formative assessment in the instruction (William, 2007, 2011)

9. Advocating on professional learning and collaboration. Effective education system in the 21st century should have a dynamic, ongoing, embedded at job, content focused professional learning. In addition, professionals should collaborate and cooperate for best practices. If the cascade model of professional development is not working for the country, it has to be replaced by other models that can fit to the context of teachers in the country.
10. Applying the principle of the "minimum barrel". We may raise questions: What types of resources are available for all learners to get quality mathematics education? How can these resources be optimized for fostering equitable access for all learners during these challenging times? What is the way forward? This principle (Liebig's law) would help us to focus on the factors that needed special attention in order to boost the quality of education.

We believe that the above ten points are worth to consider in order to boost equitable access to learners.

\section{REFERENCES}

Adamu, A. Y. (07 May 2020). COVID-19 - A Chance for Universities to Regain Public Trust? University World News. Retrieved from https://www.universityworldnews.com/post.php?story=2020050 6100321289

Ball, D. L., Thames, M. H., \& Phelps, G. (2008). Content Knowledge for Teaching. Journal of Teacher Education, 59(5), 389-407. https://doi.org/10.1177/0022487108324554

Berry, R. Q. (2019). Advocacy: Let's Work Together. NCTM. Retrieved from https://www.nctm.org/News-and-Calendar/Messagesfrom-the-President/Archive/Robert-Q_-Berry-III/AdvocacyLets-Work-Together/

Blömeke S., Olsen R.V., \& Suhl U. (2016) Relation of Student Achievement to the Quality of Their Teachers and Instructional Quality. In T. Nilsen, \& J. E. Gustafsson (Eds.), Teacher Quality, Instructional Quality and Student Outcomes. IEA Research for Education (A Series of In-depth Analyses Based on Data of the International Association for the Evaluation of Educational Achievement (IEA)) (vol 2). Cham: Springer.

Boaler, J. (1998). Open and Closed Mathematics: Student Experiences and Understandings. Journal for Research in Mathematics Education, 29(1), 41-62. https://doi.org/10.2307/749717

Boaler, J., \& Staples M. (2008). Creating Mathematical Futures through an Equitable Teaching Approach: The Case of Railside School. Teachers College Record, 110(3), 608-645.

Cai et al. (2019). Exploring the impact of a problem-posing workshop on elementary school mathematics teachers' problem posing and lesson design. International Journal of Educational Research, 102, 101404. https://doi.org/10.1016/j.ijer.2019.02.004

Cai, J., Morris, A., Hohensee, C., Hwang, S., \& Robison, V. (2020). Maximizing the Quality of Learning Opportunities for Every Student. Journal for Research in Mathematics Education, 51(1), 12-25. https://doi.org/10.5951/jresematheduc.2019.0005

Carroll, J. (1963). A model of school learning. Teachers. College Record, 64(8), 723-723.

Chapin, S. H., O'Connor, C., \& Anderson, N. C. (2003). Classroom Discussions: Using Math Talk to Help Students Learn, Grades 1-6. Math Solutions.

Chigonga, B. (2020, 26 February). Formative Assessment in Mathematics Education in the Twenty-First Century. In K. G. Fomunyam (Ed.), Theorizing STEM Education in the 21st Century. IntechOpen. https://doi.org/10.5772/intechopen.88996 
Davoli, M., \& Entorf, H. (2018). The PISA Shock, Socioeconomic Inequality, and School Reforms in Germany. Bonn, Germany: Institute of Labor Economics.

Fosnot, C. T., \& Dolk, M. (2001). Young Mathematicians at work: Constructing Multiplication and Division. Westport, CT: Heinemann.

Franke, M. L., Kazemi, E., \& Battey, D. (2007). Mathematics teaching and classroom practice. In F. K. Lester (Ed.), Second handbook of research on mathematics teaching and learning (pp. 225-253). Charlotte, NC: Information Age Publishing.

Grønmo, L. S. (2010). Low Achievement in Mathematics in Compulsory School as Evidenced by TIMSS and PISA. In B. Sriraman, C. Bergsten, S. Goodchild, G. Pálsdóttir, B. Dahl, \& L. Haapasalo (Eds.), The First Sourcebook on Nordic Research in Mathematics Education (pp. 49-69). Charlotte, NC: Information Age Publishing.

Hunzicker, J. L. (2010). Characteristics of effective professional development: a checklist. Retrieved from ERIC database (ED510366).

Kazemi, E., \& Hintz, A. (2014). Intentional talk: how to structure and lead productive mathematical discussions. Portland: Stenhouse Publishers.

Kilpatrick, J. (1987). Problem formulating: Where do good problems come from? In A. H. Schoenfeld (Ed.), Cognitive science and mathematics education (pp. 123-147). Hillsdale, NJ: Erlbaum.

Lampert, M., \& Blunk, M. L. (1998). Talking mathematics in school: Studies of teaching and learning. NewYork: Cambridge University Press. https://doi.org/10.1017/CBO9780511571251

Lave, J., \& Wenger, E. (1991). Situated learning: legitimate peripheral participation. Cambridge, MA: Cambridge University Press. https://doi.org/10.1017/CBO9780511815355

Lerman, S. (1996). Socio-cultural approaches to mathematics teaching and learning. Educational Studies in Mathematics, 31(1-2), 1-9. https://doi.org/10.1007/BF00143924

Lerman, S. (2000). The social turn in mathematics education research. In J. Boaler (Ed.), Multiple Perspectives on Mathematics Teaching and Learning (pp. 19-44). Westport, CT: Ablex. https://doi.org/10.2307/749752

McAleavy, T., Gorgen, T. K., Rodney, R., \& Proctor, J. (2020). Overview of emerging country-level response to providing educational continuity under COVID-19. Best practice in pedagogy for remote teaching. Part of our EdTech and coronavirus (COVID-19) series: https://teachertaskforce.org/sites/default/files/2020-05/researchbest-practice-pedagogy-remote-teaching.pdf

Mulenga, E. M., \& Marbán, J. M. (2020). IsCOVID-19 the gate way for digital learning in mathematics education? Contemporary Educational Technology, 12(2), ep269. https://doi.org/10.30935/ cedtech/7949

National Council of Teachers of Mathematics (NCTM) (2014). Principles to Actions: Ensuring Mathematical Success for All. Reston, VA: NCTM

National Council of Teachers of Mathematics (NCTM). (1989). Curriculum and Evaluation Standards for School Mathematics. Reston, VA: NCTM.

National Council of Teachers of Mathematics (NCTM). (1991). Professional Standards for Teaching Mathematics. Reston, VA: NCTM.
National Council of Teachers of Mathematics (NCTM). (1995). Assessment Standards for School Mathematics. Reston: NCTM.

National Council of Teachers of Mathematics (NCTM). (2000). Principles and standards for school mathematics. Reston, VA: NCTM.

NCSM, \& NCTM. (2020, June). Moving Forward: Mathematics Learning in the Era of COVID-19. Retrieved on 7 September 2020 from https://www.nctm.org/Research-and-Advocacy/MovingForward---NCSM-and-NCTM-Joint-Statement/

Neubrand, M., Seago, N., Agudelo-Valderrama, C., DeBlois, L., Leikin, R., \& Wood, T. (2009). The Balance of Teacher Knowledge: Mathematics and Pedagogy. In R. Even, \& D. L. Ball (Eds.), The Professional Education and Development of Teachers of Mathematics (pp. 211-225). New ICMI Study Series, vol 11. Boston, MA: Springer. https://doi.org/10.1007/978-0-387-09601-8_21

Organisation for Economic Cooperation and Development (OECD). (2016). PISA 2015 results (Vol I): Excellence and Equity in Education. Paris: PISA, OECD Publishing. https://doi.org/10.1787/ 9789264266490-en

Radcliffe, J. S., Aaron, D. K., Sterle, J., Keyserlingk, M. A. G, Irlbeck, N., Maquivar, M., Wulster-Radcliffe, M., \& Jones, C. (2020). Moving online: roadmap and long-term forecast. Animal Frontiers, 10(3), 36-45. https://doi.org/10.1093/af/vfaa027

Reimers, F. M., \& Schleicher, A. (2020). A framework to guide an education response to the COVID-19 Pandemic of 2020. OECD. Retrieved on 15 May 2020 from https://globaled.gse.harvard.edu/ files/geii/files/framework_guide_v2.pdf

Silver, E. A. (1997). Fostering creativity through instruction rich in mathematical problem solving and problem posing. ZDM, 29, 7880. https://doi.org/10.1007/s11858-997-0003-x

Smith, M., \& Stein, M. K. (2011). 5 practices for orchestrating productive mathematics discussions. Reston: NCTM.

Stein, M. K., \& Smith, M. S. (1998). Mathematical tasks as a framework for reflection: From research to practice. Mathematics Teaching in the Middle School, 3(4), 268-275. https://doi.org/10.5951/ MTMS.3.4.0268

Stein, M. K., Grover, B. W., \& Henningsen, M. (1996). Building Student Capacity for Mathematical Thinking and Reasoning: An Analysis of Mathematical Tasks Used in Reform Classrooms. American Educational Research Journal, 33(2), 455-488. https://doi.org/10.3102/00028312033002455

Tanton, J. (2020, 18 April). COVID-19 Exposes Mathematics Education Inadequacies: A modicum of (secret) relief for Educators. Retrieved from https://medium.com/

Tesfamicael, S. A. (2019). Discussion points for Reform in Mathematics education in Ethiopia. Making Science and Mathematics Teaching and Learning Impactful.International Conference on Science and Mathematics Education from October 23-24, 2019.

Tesfamicael, S. A., Taye, D., Belay, G., Tulu, A., \& Tesfay, A (2018). Comparative Study: The case of mathematics Teacher Preparation (MTP) programs in Norway and Ethiopia. AFRICME 5, 2018, International Mathematical Union (IMU); 29-31/08/2018. 
Tesfamicael, S., \& Lundeby, Ø. (2019). A Comparative Study of Norwegian and Ethiopian Textbooks: The Case of Relations and Functions Using Anthropological Theory of Didactics (ATD). Universal Journal of Educational Research, 7(3), 754-765. https://doi.org/10.13189/ujer.2019.070315

Tesfamicael, S., Botten, G., \& Lundeby, Ø. (2017). The teaching and learning of relations and functions: A comparative study of Norwegian and Ethiopian textbooks. Proceedings of CERME 10, Dublin, Ireland.

Tiruneh, D. T. (2020, June). COVID-19 School Closures May Further Widen the Inequality Gaps between the Advantaged and the Disadvantaged in Ethiopia. Retrieved from https://www.cambridge.org/gb/partnership/insights/COVID19-school-closures-may-further-widen-inequality-gaps-betweenadvantaged-and-disadvantaged-ethiopia

Van Veen, K., Zwart, R. C., \& Meirink, J. (2012). What makes teacher professional development effective? A literature review. In M. Kooy, \& K. van Veen (Eds.), Teacher learning that matters: International perspectives (Routledge research in education, vol. 62, pp. 3-21). Routledge.
Walkowiak, T. A., Pinter, H. H., \& Berry, R. Q. (2017). A Reconceptualized Framework for 'Opportunity to Learn' in School Mathematics. Journal of Mathematics Education at Teachers College, 8(1), 7-18. https://doi.org/10.7916/jmetc.v8i1.800

Wenger, E. (1998). Communities of practice: learning, meaning and identity. Cambridge, MA: Cambridge University Press. https://doi.org/10.1017/CBO9780511803932

Wiliam, D. (2007). Keeping Learning on Track: Classroom Assessment and the Regulation of Learning. In F. K. Lester, Jr. (Ed.), Second Handbook of Mathematics Teaching and Learning (pp. 1053-1098). Charlotte, N.C.: Information Age.

Wiliam, D. (2011). Embedded Formative Assessment. Bloomington, Ind.: Solution Tree Press.

Yoon, K. S., Duncan, T., Lee, S. W.-Y., Scarloss, B., \& Shapley, K. (2007). Reviewing the evidence on how teacher professional development affects student achievement (Issues \& Answers Report, REL 2007-No. 033). Washington, DC: U.S. Department of Education, Institute of Education Sciences, National Center for Education Evaluation and Regional Assistance, Regional Educational Laboratory Southwest. 